DE DE GRUYTER OPEN
Przedsiębiorczość i Zarządzanie Entrepreneurship and Management University od Social Sciences Publishing House ISSN 1733-2486

Volume XVI, Issue 1, pp. 39-50

DOI 10.1515/eam-2015-0003

Agnieszka Jachowicz

University of Dąbrowa Górnicza

\title{
Fiscal Policy in European Union Countries in Time of the Economic Crisis - Attempt to Estimation
}

\begin{abstract}
:
In this article, stability of fiscal policy and its impact on fiscal market have been analyzed. The issue appears especially important in times of the financial crisis which has affected all the European Union countries, although to a different extent. To achieve this, the author presented the aims, the tools and the aspects of financial stability to confront them with the situation that has occurred in the EU countries. To present the issue profoundly, the scientific research related to fiscal policy and its impact on financial markets were used in two opening units. In the third unit, the statistic data was cited to show the condition of the EU countries, the changes to it and the attempts aimed at improving the state of the public finance and therefore stabilizing financial markets.
\end{abstract}

Key words: fiscal policy, stability of fiscal policy, financial crisis.

\section{Introduction}

The latest financial crisis, which began in 2008, posed some new challenges to fiscal policy. The speed of its spreading and the fluctuation of financial markets which accompanied it, caused the need to turn to fiscal policy as a tool of countercyclical policy. The aim of this article is to present stability of fiscal policy in combating financial crisis. The author described the aims of fiscal policy together with the tools which can be used to stimulate economy. Next, some conceptions of fiscal stability were presented as well as their importance for economy and financial markets. Furthermore, the author showed the effects of 
the crisis on fiscal policy and the attempts to stabilize it with stimulating packages and fiscal reforms. Those are used to solve the problems of liquidity and solvency, not only to increase demand, but mainly to try to help the threatened financial sector. The question how to reconcile the weakened economic growth with the attempts to bring back stability of the public finances and financial markets, is still very much an open one.

\section{The aim and the tools of financial policy}

The term „financial policy” is not univocally understood in specialist literature. The word ,fiscal” has its Latin roots and in Ancient Rome meant a basket, into which the money for the emperor was collected. This limited meaning would signify that fiscal policy only stands for accumulating profits without taking into account expenditures. For this reason, the contemporary perception of fiscal policy takes a wider approach. Nowadays, the meaning embraces budgetary policy, serving social and economic policies which are responsible for managing public resources by the public sector entities and especially for processes related to accumulating public resources and distributing them [Musgrave, Musgrave 1989, p. 3].

In Polish specialist literature the terms "fiscal policy" and "budgetary policy” are synonyms [Wersalski 1997, p. 16]. Individual authors concentrate, however, on emphasizing the economic and social consequences of using fiscal instruments. N. Gajl states that fiscal policy encompasses the whole of intended economic activities taken by the government in order to do different economic tasks aided by financial instruments, mainly taxation [Gajl 1988, p. $14]$. Z. Fedorowicz stresses that fiscal policy is based on a choice of sources and methods of gaining public income to achieve social and economic goals established by appriopriate public institutions, therefore it is often identified with the financial policy of the state [Fedorowicz 1998, p. 11]. However, according to the definition from "Finance Lexicon" [2001, p. 221], fiscal policy means the activities of the state based on fiscal instruments (i.e. taxation, other public income, public expenses or budgetary deficit), aiming at achieving given goals.

The countries which accepted the market mechanism and the rules governing it, influence economy for two main reasons. Firstly, the forming of economic processes needs coordination and action from the state. Secondly, in a democratic system, the state has not been excused from responsibility for economic processes. Using two kinds of monetary instruments, the state can influence economy. These tools are used in two domains of economy, mainly in monetary and fiscal polices. While the monetary policy focuses on, among others, protection of the money's value and regulating money supply, fiscal 
policy deals with supplying the state with necessary income. Generally speaking, they serve global purposes i.e. economic growth, fighting unemployment, limiting the amplitude of market situation fluctuations etc. [Owsiak 2013, p. 359]. In the following section of the article the author's attention will mainly be focused on fiscal policy.

The skill of fiscal policy is to combine its basic aims (supplying the state with necessary monetary means) with simultaneously achieving important economic and social aims by the state. More precisely, fiscal policy uses three basic methods of influencing economy:

- changes in purchasing goods and services by the state;

- changes in transfer payments;

- changes in taxes.

Indirectly, the state influences the demand through changes in transfers and taxation, thus influencing consumption. Through purchasing goods and services it directly influences demand [Hall, Taylor 2010, p. 264]. Quoting after Owsiak [2013]: to achieve goals of fiscal policy in the general meaning, one can use, among others ways, taxation instruments, the unemployed benefit, expenses on restructuring economy, public expenses towards public works, budgetary deficit, public debt as well as sureties and guarantees from the state, granted the entities which take out loans. Achieving out of fiscal goals while using aforementioned goals is not easy as the state's interference is beneficial to some economic entities, but not to the others. Despite many different opinions about the issue of the state's interference into the market mechanism, the question of stability, which should be a drive for fiscal policy, does not cause divisions.

\section{The conception of fiscal stability and its importance}

The meaning of fiscal stability comes down to maintaining public debt within reasonable limits. "Reasonable" here should be understood as the level which would ensure the minimal negative effects of public debt and budgetary deficit on the economy, allowing to fullfil the state's duties with regards to stabilizing the economy [Wlodarczyk 2011, p. 8]. Fiscal stability should mean activities which, in the long run, will guarantee the access to financing expenses, preventing changes caused by financial difficulties and contributing to stabilizing the whole economy.

O.J. Blanchard [1990, s.11] states that we could look at fiscal policy as the inherited level of indebtedness. We shall consider fiscal policy as stable when it assures the relation between the debt and GDP heading towards the starting level. Over a long period of time, real public debt should not grow faster than the interest rates and the indicator - debt/GDP should not grow faster than 
the the difference between the pace of economic growth and interest rates. The influence of Keynes' conception, which approves expansive fiscal policy, can be seen here. However, after a period of good economic situation, it appears desirable to normalize the fiscal situation of the state through stimulating the relation debt/GDP.

If fiscal policy is based on creating budgetary deficit, such activities have influence on the goods and monetary markets, which questions the possibility of achieving a long term stability. The conception of fiscal stability should be used to prevent uncontrolled growth of indebtedness, which in turn contributes to destabilisation of the economic system and financial markets, especially in the era of integration and globalisation, which enforce and intensify these processes. It is, therefore, advisable to monitor the fiscal situation of the country with the view to establishing which tendency will develop the budgetary imbalance and which will lead to its decrease [Kosterna 1995, pp. 125-127].

The question which is worth thinking over, is the issue of researching its influence on economy. O. J. Blanchard [1985] and H. Bohn [1995] focus on the general balance models which were used to research the influence of fiscal stability conceptions on the developing and applying economic policy instruments as well as economic entities' decisions. P.Burger

[2003] linked budgetary limitations of the government with the fiscal situation of remaining economic entities as well as the whole economy. To form his theory, Burger used J. Tobin's idea. Tobin thought that keeping deficits by the public sector means keeping surpluses by the non-public sector (i.e. private and foreign). As a consequence, we shall look at fiscal stability from the perspective of changes which it brings about in the financial situation of individual sectors. Balancing individual factors: households, businesses, financial sector, foreign sector as well as the whole economy, which referred to GDP enables monitoring changes in financial stability [Burger 2003, pp. 80-90].

The model described here enables us to draw interesting conclusions. P. Burger stressed that the changes in the state's fiscal policy, focused on linking the ratio debt/GDP, do not necessarily result in a tendency to get financial surpluses by the owners of assets in order to stabilise the indicator assets/GDP at the same level as before. Moreover, increased access to the capital could result in net debtors taking out new loans in other sectors and thus worsening fiscal situation. As a result, fiscal policy stability could disturb this balance and transfer this imbalance into other sectors. The latest financial crisis proved strong intersector interdependence between the economic entities and their financial positions, focusing mainly on joining fiscal policy with governmental public sector, overlooking non-governmental sector and general financial stability. 
T.J. Sergeant and N. Wallace [1981, pp. 3-5] pointed out the issue of coordinating monetary and fiscal policies and their influence on inflation tendencies. They noticed that in economies where monetarism prevails and fiscal policy is paramount to monetary policy, focusing on restrictive monetary policy which aims at limiting inflation may, in the future, result in the necessity to loosen it up and, as a consequence, in higher inflation. Where monetary authorities are limited by the demand for treasury bonds, deficit is to be financed by segniorage. Restrictive monetary policy means the increase in interest rates, which translates into higher debt service. If interest rates are higher than the economic growth rates, the central bank could be pressurised to loosen up monetary policy to finance the high deficit level, caused by the lack of backing in the sold bonds, which translates into inevitable growth in inflation. Recovering fiscal stability should be aimed at limiting the debt not at financing it with segniorage. Eventually, restrictive monetary policy should bring benefits, reduce inflation, while monetary authorities should gain freedom to implement their own policies [Wlodarczyk 2011, pp. 24-25].

Fiscal policy, especially an unstable one, undoubtedly has influence on the increase in taxes, which in turn limits economic growth. The costs of debt service are rising, thus worsening the fiscal and economic situation of the country. Monetarisation in an option, but that could bring about hiperinflation, or even repudiation. Only introducing stable fiscal policy could limit the height of the interest rates leading to faster economic growth and stability of financial markets [Fullwiler 2007, s. 1011].

The conception of "tax-smoothing" is important to fiscal policy. According to R.J. Barro [1979] and D. Romer [2006], deriving income from taxes is linked to raising the costs of collecting them and incorrect allocation of resources by private entities. The most desirable solution would be to use, over a long period of time, the whole tax rate against the aggregated income, which will help to determine the level of public debt in the specified periods. Thanks to stable fiscal policy, public debt will be limited and brought to a certain level. This way of conducting fiscal policy seems the most rational, also from the future generation's perspective as they will endure that tax.

To finish reflecting on the meaning of fiscal policy, it is worth mentioning the state's credibility on financial markets, which face high deficits. The loss of such credibility could mean not only the lack of opportunities to gain funding, but also problems with granting credits to the individual entities as well as lower influx of foreign investments [Wiernik 2007, p. 99]. One of the examples of credibility put into a trial was the latest economic crisis. 
Fiscal policy in the European Union countries during the crisis on financial markets

Most countries with a large public debt did not take advantage of the good situation before the crisis to consolidate public finances. Moreover, some countries would have to reconcile two contradictory aims. On the one hand, they need to look after the pace of the economic growth, which is slow during the crisis. On the other hand, they need to ensure the stability of public finances, as the lack of it threatens with the lack of economic growth. This is because the thriving economy can only partly soothe the budgetary and financial markets tensions in the countries with the biggest public debt growth (table 1).

Table 1. Public debt as \% of GDP in 2001-2012

\begin{tabular}{|c|c|c|c|c|c|c|c|c|}
\hline $\begin{array}{c}\text { Countries/ } \\
\text { year }\end{array}$ & 2001 & 2004 & 2006 & 2008 & 2009 & 2010 & 2011 & 2012 \\
\hline Belgium & $\mathbf{1 0 6 , 5}$ & $\mathbf{9 4}$ & $\mathbf{8 7 , 9}$ & $\mathbf{8 9 , 2}$ & $\mathbf{9 5 , 7}$ & $\mathbf{9 5 , 7}$ & $\mathbf{9 8}$ & $\mathbf{9 9 , 8}$ \\
\hline Bulgaria & 66 & 37 & 21,6 & 13,7 & 14,6 & 16,2 & 16,3 & 18,5 \\
\hline $\begin{array}{c}\text { Czech } \\
\text { Republik }\end{array}$ & 23,9 & 28,9 & 28,3 & 28,7 & 34,6 & 38,4 & 41,4 & 46,2 \\
\hline Denmark & $\mathbf{4 9 , 6}$ & $\mathbf{4 5 , 1}$ & $\mathbf{3 2 , 1}$ & $\mathbf{3 3 , 4}$ & $\mathbf{4 0 , 7}$ & $\mathbf{4 2 , 7}$ & $\mathbf{4 6 , 4}$ & $\mathbf{4 5 , 4}$ \\
\hline Germany & $\mathbf{5 9 , 1}$ & $\mathbf{6 6 , 2}$ & $\mathbf{6 8}$ & $\mathbf{6 6 , 8}$ & $\mathbf{7 4 , 5}$ & $\mathbf{8 2 , 5}$ & $\mathbf{8 0}$ & $\mathbf{8 1}$ \\
\hline Estonia & $\mathbf{4 , 8}$ & 5 & 4,4 & 4,5 & 7,1 & 6,7 & 6,1 & 9,8 \\
\hline Ireland & $\mathbf{3 4 , 5}$ & $\mathbf{2 9 , 4}$ & $\mathbf{2 4 , 6}$ & $\mathbf{4 4 , 2}$ & $\mathbf{6 4 , 4}$ & $\mathbf{9 1 , 2}$ & $\mathbf{1 0 4 , 1}$ & $\mathbf{1 1 7 , 4}$ \\
\hline Greece & $\mathbf{1 0 3 , 7}$ & $\mathbf{9 8 , 9}$ & $\mathbf{1 0 7 , 5}$ & $\mathbf{1 1 2 , 9}$ & $\mathbf{1 2 9 , 7}$ & $\mathbf{1 4 8 , 3}$ & $\mathbf{1 7 0 , 3}$ & $\mathbf{1 5 6 , 9}$ \\
\hline Spain & $\mathbf{5 5 , 6}$ & $\mathbf{4 6 , 3}$ & $\mathbf{3 9 , 7}$ & $\mathbf{4 0 , 2}$ & $\mathbf{5 4}$ & $\mathbf{6 1 , 7}$ & $\mathbf{7 0 , 5}$ & $\mathbf{8 6}$ \\
\hline France & $\mathbf{5 6 , 9}$ & $\mathbf{6 5}$ & $\mathbf{6 4}$ & $\mathbf{6 8 , 2}$ & $\mathbf{7 9 , 2}$ & $\mathbf{8 2 , 4}$ & $\mathbf{8 5 , 8}$ & $\mathbf{9 0 , 2}$ \\
\hline Italy & $\mathbf{1 0 8 , 3}$ & $\mathbf{1 0 3 , 7}$ & $\mathbf{1 0 6 , 3}$ & $\mathbf{1 0 6 , 1}$ & $\mathbf{1 1 6 , 4}$ & $\mathbf{1 1 9 , 3}$ & $\mathbf{1 2 0 , 7}$ & $\mathbf{1 2 7}$ \\
\hline Croatia & $\cdot$ & $\cdot$ & $\cdot$ & $\cdot$ & 36,6 & 44,9 & 51,6 & 55,5 \\
\hline Cyprus & $\mathbf{6 1 , 2}$ & $\mathbf{7 0 , 9}$ & $\mathbf{6 4 , 7}$ & $\mathbf{4 8 , 9}$ & 58,5 & 61,3 & $\mathbf{7 1 , 5}$ & $\mathbf{8 6 , 6}$ \\
\hline Latvia & 14,1 & 15 & 10,7 & 19,8 & 36,9 & 44,4 & 41,9 & 40,6 \\
\hline Lithuania & $\mathbf{2 3}$ & 19,3 & 17,9 & 15,5 & 29,3 & 37,8 & 38,3 & 40,5 \\
\hline Luxembourg & $\mathbf{6 , 3}$ & $\mathbf{6 , 4}$ & $\mathbf{6 , 7}$ & $\mathbf{1 4 , 4}$ & $\mathbf{1 5 , 5}$ & $\mathbf{1 9 , 5}$ & $\mathbf{1 8 , 7}$ & $\mathbf{2 1 , 7}$ \\
\hline Hungary & 52,7 & 59,5 & 65,9 & 73 & 79,8 & 82,2 & 82,1 & $\mathbf{7 9 , 8}$ \\
\hline
\end{tabular}




\begin{tabular}{|c|c|c|c|c|c|c|c|c|}
\hline Malta & 58,9 & $\mathbf{6 9 , 8}$ & $\mathbf{6 2 , 5}$ & $\mathbf{6 0 , 9}$ & $\mathbf{6 6 , 5}$ & 66,8 & 69,5 & $\mathbf{7 1 , 3}$ \\
\hline Netherlands & $\mathbf{5 0 , 7}$ & $\mathbf{5 2 , 4}$ & $\mathbf{4 7 , 4}$ & $\mathbf{5 8 , 5}$ & $\mathbf{6 0 , 8}$ & $\mathbf{6 3 , 4}$ & $\mathbf{6 5 , 7}$ & $\mathbf{7 1 , 3}$ \\
\hline Austria & $\mathbf{6 6 , 8}$ & $\mathbf{6 4 , 7}$ & $\mathbf{6 2 , 3}$ & $\mathbf{6 3 , 8}$ & $\mathbf{6 9 , 2}$ & $\mathbf{7 2 , 3}$ & $\mathbf{7 2 , 8}$ & $\mathbf{7 4}$ \\
\hline Poland & 37,6 & 45,7 & 47,7 & 47,1 & 50,9 & 54,9 & 56,2 & 55,6 \\
\hline Portugal & $\mathbf{5 3 , 8}$ & $\mathbf{6 1 , 9}$ & $\mathbf{6 9 , 4}$ & $\mathbf{7 1 , 7}$ & $\mathbf{8 3 , 7}$ & $\mathbf{9 4}$ & $\mathbf{1 0 8 , 2}$ & $\mathbf{1 2 4 , 1}$ \\
\hline Romania & 25,7 & 18,7 & 12,4 & 13,4 & 23,6 & 30,5 & 34,7 & 37,9 \\
\hline Slovenia & 26,5 & 27,3 & 26,4 & 22 & 35,2 & 38,7 & 47,1 & 54,4 \\
\hline Slovakia & 48,9 & 41,5 & 30,5 & $\mathbf{2 7 , 9}$ & 35,6 & 41 & 43,4 & 52,4 \\
\hline $\begin{array}{c}\text { Finland } \\
\mathbf{4 2 , 5}\end{array}$ & $\mathbf{4 4 , 4}$ & $\mathbf{3 9 , 6}$ & $\mathbf{3 3 , 9}$ & $\mathbf{4 3 , 5}$ & $\mathbf{4 8 , 7}$ & $\mathbf{4 9 , 2}$ & $\mathbf{5 3 , 6}$ \\
\hline Sweden & $\mathbf{5 4 , 7}$ & $\mathbf{5 0 , 3}$ & $\mathbf{4 5 , 3}$ & $\mathbf{3 8 , 8}$ & $\mathbf{4 2 , 6}$ & $\mathbf{3 9 , 4}$ & $\mathbf{3 8 , 6}$ & $\mathbf{3 8 , 2}$ \\
\hline $\begin{array}{c}\text { United } \\
\text { Kingdom }\end{array}$ & $\mathbf{3 7 , 3}$ & $\mathbf{4 0 , 3}$ & $\mathbf{4 2 , 7}$ & $\mathbf{5 1 , 9}$ & $\mathbf{6 7 , 1}$ & $\mathbf{7 8 , 4}$ & $\mathbf{8 4 , 3}$ & $\mathbf{8 8 , 7}$ \\
\hline
\end{tabular}

Source: own study on the base of Eurostat (download 21.02.2014).

It is worth noticing that, after 2008, from the beginning of the financial crisis, the debt in all the EU countries has grown, which means that all those countries had to react with active fiscal policies, wanting to soothe its consequences. The only exception is Sweden, where public debt has decreased from 2001, apart from 2009, when it grew by 3.8 p.p., to decrease again. It is especially interesting as Sweden represents a typical caring country, characterised by high social expenses. It shows that "dismantling" a caring country is not needed. What is required is reforms and, at the same, time monitoring integration and globalisation issues. Among "the old 15" of the EU, the worst situation was visible in Ireland, Greece, Italy or Portugal, where public debt went over 100\% GDP. As for the new members, Estonia was the least indebted, whereas Cyprus, Hungary and Malta exceeded the level of 60\% GDP. The worst situation was in Cyprus and Hungary, which reflected on financial markets.

Looking at GDP rates (table 2), where there was economic growth in all the EU countries until 2008 (with the exception of Malta in 2004), after that year the positions differentiated. 
Table 2. GDP rates (\%) year to year

\begin{tabular}{|c|c|c|c|c|c|c|c|c|}
\hline $\begin{array}{c}\text { Countries/ } \\
\text { year }\end{array}$ & 2002 & 2004 & 2006 & 2008 & 2009 & 2010 & 2011 & 2012 \\
\hline Belgium & 1,4 & 3,3 & 2,7 & 1 & $-2,8$ & 2,3 & 1,8 & $-0,1$ \\
\hline Bulgaria & 4,7 & 6,7 & 6,5 & 6,2 & $-5,5$ & 0,4 & 1,8 & 0,8 \\
\hline $\begin{array}{l}\text { Czech } \\
\text { Republik }\end{array}$ & 2,1 & 4,7 & 7 & 3,1 & $-4,5$ & 2,5 & 1,8 & -1 \\
\hline Denmark & 0,5 & 2,3 & 3,4 & $-0,8$ & $-5,7$ & 1,4 & 1,1 & $-0,4$ \\
\hline Germany & 0 & 1,2 & 3,7 & 1,1 & $-5,1$ & 4 & 3,3 & 0,7 \\
\hline Estonia & 6,6 & 6,3 & 10,1 & $-4,2$ & $-14,1$ & 2,6 & 9,6 & 3,9 \\
\hline Ireland & 5,4 & 4,2 & 5,5 & $-2,2$ & $-6,4$ & $-1,1$ & 2,2 & 0,2 \\
\hline Greece & 3,4 & 4,4 & 5,5 & $-0,2$ & $-3,1$ & $-4,9$ & $-7,1$ & $-6,4$ \\
\hline Spain & 2,7 & 3,3 & 4,1 & 0,9 & $-3,8$ & $-0,2$ & 0,1 & $-1,6$ \\
\hline France & 0,9 & 2,5 & 2,5 & $-0,1$ & $-3,1$ & 1,7 & 2 & 0 \\
\hline Croatia & 4,9 & 4,1 & 4,9 & 2,1 & $-6,9$ & $-2,3$ & $-0,2$ & $-1,9$ \\
\hline Italy & 0,5 & 1,7 & 2,2 & $-1,2$ & $-5,5$ & 1,7 & 0,5 & $-2,5$ \\
\hline Cyprus & 2,1 & 4,2 & 4,1 & 3,6 & $-1,9$ & 1,3 & 0,4 & $-2,4$ \\
\hline Latvia & 7,1 & 8,8 & 11 & $-2,8$ & $-17,7$ & $-1,3$ & 5,3 & 5,2 \\
\hline Lithuania & 6,8 & 7,4 & 7,8 & 2,9 & $-14,8$ & 1,6 & 6 & 3,7 \\
\hline Luxembourg & 4,1 & 4,4 & 4,9 & $-0,7$ & $-5,6$ & 3,1 & 1,9 & $-0,2$ \\
\hline Hungary & 4,5 & 4,8 & 3,9 & 0,9 & $-6,8$ & 1,1 & 1,6 & $-1,7$ \\
\hline Malta & 2,4 & $-0,3$ & 2,6 & 3,9 & $-2,8$ & 3,3 & 1,7 & 0,9 \\
\hline Netherlands & 0,1 & 2,2 & 3,4 & 1,8 & $-3,7$ & 1,5 & 0,9 & $-1,2$ \\
\hline Austria & 1,7 & 2,6 & 3,7 & 1,4 & $-3,8$ & 1,8 & 2,8 & 0,9 \\
\hline Poland & 1,4 & 5,3 & 6,2 & 5,1 & 1,6 & 3,9 & 4,5 & 1,9 \\
\hline Portugal & 0,8 & 1,6 & 1,4 & 0 & $-2,9$ & 1,9 & $-1,3$ & $-3,2$ \\
\hline Romania & 5,1 & 8,5 & 7,9 & 7,3 & $-6,6$ & $-1,1$ & 2,2 & 0,7 \\
\hline Slovenia & 3,8 & 4,4 & 5,8 & 3,4 & $-7,9$ & 1,3 & 0,7 & $-2,5$ \\
\hline
\end{tabular}




\begin{tabular}{|c|c|c|c|c|c|c|c|c|}
\hline Slovakia & 4,6 & 5,1 & 8,3 & 5,8 & $-4,9$ & 4,4 & 3 & 1,8 \\
\hline Finland & $\mathbf{1 , 8}$ & $\mathbf{4 , 1}$ & $\mathbf{4 , 4}$ & $\mathbf{0 , 3}$ & $\mathbf{- 8 , 5}$ & $\mathbf{3 , 4}$ & $\mathbf{2 , 8}$ & $-\mathbf{1}$ \\
\hline Sweden & $\mathbf{2 , 5}$ & $\mathbf{4 , 2}$ & $\mathbf{4 , 3}$ & $-\mathbf{0 , 6}$ & $\mathbf{- 5}$ & $\mathbf{6 , 6}$ & $\mathbf{2 , 9}$ & $\mathbf{0 , 9}$ \\
\hline $\begin{array}{c}\text { United } \\
\text { Kingdom }\end{array}$ & $\mathbf{2 , 3}$ & $\mathbf{3 , 2}$ & $\mathbf{2 , 8}$ & $-\mathbf{0 , 8}$ & $\mathbf{- 5 , 2}$ & $\mathbf{1 , 7}$ & $\mathbf{1 , 1}$ & $\mathbf{0 , 3}$ \\
\hline
\end{tabular}

Source: own study on the base of Eurostat (download 21.02.2014).

The worst situation occurred in Greece, where GDP has taken negative values from the beginning of the crisis. Similarly, Croatia - also a new member, has noted the decrease in GDP after 2009. In Ireland, deeply affected by the crisis, it has been possible to achieve a positive GDP since 2010. The only country without the negative values in GDP was Poland, whose public debt has not exceeded 60\% GDP. For this reason, there were no difficulties selling treasury bonds on financial markets. Very sharp falls in GDP have been noted in Estonia after 2009 (-14\%), Latvia $(-17,7 \%)$ or Lithuania $(-14,8 \%)$, in which positive economic growth has been observed in subsequent years. The situation has improved to such an extend that Estonia was accepted to the euro area.

It is worth looking at the average nominal interest rate calculated for treasury bonds. The highest nominal rates were observed in Greece $(9,09 \%$ in $2010 ; 15,75 \%$ in 2011$)$, Portugal $(10,24 \%$ in 2011$)$ and Ireland $(9,6 \%$ in 2011), which is a proof of the difficult situation in these countries. After 2008 the rate for "the old 15" has fluctuated around 4\%, except for Great Britain, where it amounted to 5,6\%. Regarding the new members, the highest rate was for Hungary and Romania, $6.7 \%$ and $7.13 \%$ respectively. At the end of 2011 the lowest rate was for Denmark (2,73\% in 2011), Sweden $(2,61 \%$ in 2011) and Great Britain (2,87\% in 2011) - the countries outside the euro area. Among the countries within the euro area only Luxembourg and Holland had the rate below 3\%. The proof of trust in financial markets was the influx of foreign investments. According to Eurostat's data [2013] at the turn of 2009/2011 the highest amount of such investments was noted in Luxembourg, on average $35.7 \%$, followed by Great Britain with $16.7 \%$, Germany $-8.9 \%$, France $-6.7 \%$ and Sweden $-4.1 \%$. These countries have been affected by the crisis, nevertheless their fiscal policy has been conducted in a way, which in investors' opinions enables to stay optimistic and proved efficient.

The financial crisis, which translated into deteriorating the relation between public debt and GDP deficit, was made worse by the activities from the automatic market situation stabilisers, as well as the use of discretional fiscal policy instruments - stimulating packages, mainly through direct financial aid 
for the financial sector. Since 2010 budgetary deficits have decreased, despite the fact that the pace of this phenomenon has depended on the specific situation of the country. Consolidation is being continued in the euro area, especially in these countries which contributed to the debt crisis in this group. Namely in Greece, Ireland and Portugal. To avoid insolvency and improve credibility of fiscal reform, these countries had to implement consolidation instruments to be able to apply for bail- outs offered by the EU/IMF.

Another factor, thanks to which the situation gets more complex, is the tendency to open economies in conditions of globalization and integration, which lowers the effectivness of fiscal policy. During the latest crisis, there were a lot of debates regarding conducting fiscal policy. According to the economists from the IMF, for the fiscal stimulus to ensure stability over a long period of time, it has to be implemented immediately, at a large scale and have a long term duration. It should also be differentiated, taking into consideration the instruments used and implemented in the large number of countries. The choice of the scale and the instruments should be also based on the solvency of the government, builds trust from financial markets - a key factor in stability and economic prosperity.

As the experiences of the last few years have proven, the fiscal consolidation based on expenditure, resulting in limiting public debt, is not enough. It is true that the fiscal consolidation based on expenditure cuts brings long lasting affects more effectively than the one based on the tax rises, but the latter could be effective providing the tax base is wider and the taxation systems - more simple. The good examples are the Baltic States. Quick consolidation could cause Keynes' effects, meaning the fall in production level and the rise in unemployment, which is already apparent in the EU. If, together with the consolidation, there are also such factors as cutting interest rates, the fall of the national currency and the growth in export, the effects are milder, which is visible looking at Poland, but not at the euro area.

This does not calm down financial markets.

\section{Conclusion}

The aim of fiscal policy of the future should become to counterpart speculative bubbles, which pose a threat to financial markets in terms of their reliability and credibility. To make that possible, the instruments of fiscal stimulation should be carefully prepared and introduced as well as properly implemented according to the situation of the particular economy. Internal imbalances and instability of the financial systems of specific countries contributed to worsening the crisis, causing the domino effect. The choice of the scale and the fiscal 
instruments depends on fiscal stability over a medium and long period of time as it creates trust in the government and therefore the conditions for economic prosperity and financial markets development. Postponing stabilizing public finances will not bring anything good, on the contrary, it could destabilize the expectations of the economic entities, increasing the cost of government credits. Achieving the balance between contradictory aims will pose one of the biggest challenges, especially in times of progressing integration.

\section{Bibliography}

Barro R.J. (1979), On the Determination of the Public Debt, "Journal of Political Economy", Vol. 87, No. 5, Part 1.

Begg D., Fiszer S., Dornbusch R. (2000), Makroekonomia, PWE, Warszawa.

Blanchard O.J. (1985), Debt, Deficits and Finite Horizons, "Journal of Political Economy", Vol. 93, No.2.

Blanchard O.J. (1990), Suggestions for a New Set of Fiscal Indicators, OECD Department of Economics and Statistics Working Papers, No.79.

Bohn H. (1995), The Sustainability of Budget Deficits in a Stochastic Economy, "Journal of Money Credit and Banking", Vol. 27, No. 1.

Burger P. (2003), Sustainable Fiscal Policy and Economic Stability. Theory and Practice, Edward Elgar, Cheltenham, UK, Northhampton, MA, USA.

Fedorowicz Z. (1988), Polityka fiskalna Wydawnictwo Wyższej Szkoły Bankowej, Poznań.

Fullwiler S.T. (2007), Interest Rates and Fiscal Sustainability, "Journal of Economic Issues", Vol. 41, No. 4.

Gajda-Kantorowska M. (2011), Analiza przydatności polityki fiskalnej do usuwania skutków kryzysu w krótkim, średnim i dtugim okresie [in:] Polityka makroekonomiczna w warunkach kryzysu i jej wptyw na gospodarkę. Teoria i praktyka, ed. Z. Dach, Oficyna Wolters Kluwer, Warszawa.

Gajl N. (1988) Instrumenty finansowe w zarzadzaniu gospodarka narodowa, PWE, Warszawa.

Hall R.E., Taylor J.B. (2010), Makroekonomia, PWN Warszawa.

Kosterna U. (1995), Deficyt budżetu państwa i jego skutki ekonomiczne, Wyd. Naukowe PWN, Warszawa.

Leksykon Finansów (2001), PWE, Warszawa.

Musgrave R.A., Musgrave P.B. (1989) Public finance in theory and practice, McGraw - Hill International Editions, New York.

Raport „Key figures on Europe” [2013], Eurostat. 
Romer D. (2006), Advanced Macroeconomics. The McGraw-Hill Companies, New York.

Sargent T.J., Wallace N. (1981), Some Unpleasant Monetarist Arithmetic, Federal Reserve Bank of Minneapolis Quarterly Review, Fall.

Owsiak S. (2013), Finanse publiczne. Teoria i praktyka, Wydawnictwo Naukowe PWN, Warszawa.

Wersalski M. (1997), Polityka budżetowa, PWE, Warszawa.

Wernik A. (2007), Finanse publiczne. Cele. Struktury. Uwarunkowania, PWE, Warszawa.

Włodarczyk P. (2011), Stabilność fiskalna - koncepcja teoretyczna i jej znaczenie praktyczne. Analiza na przyktadzie państw Grupy Wyszehradzkiej w latach 1995 2009, „Materiały i Studia”, nr 256. 